\title{
A Case Study in Latin American Literature: Ilan Stavans' On Borrowed Words
}

\section{Introductory remarks}

As mentioned in the editors' prologue, this project seeks to integrate paradigmatic Jewish literary texts, selected passages and issues into a modern syllabus of philological studies. They (i.e., the studies) often comprise a very reduced proportion of modules in literature and, furthermore, still tend to stick to outdated concepts of "national" literature, despite transnational and globalized movements, or rather, new media- and ethnoscapes, as Appadurai calls them, that challenge these concepts. To achieve such an outcome, texts must be paradigmatic and exemplary across a variety of disciplines. Additionally, they must offer a certain degree of accessibility and amenability to undergraduate students so they can be easily incorporated into an academic syllabus (in Germany and/or other countries).

This volume offers a broad thematic spectrum, which, in essence, deals with two fundamental questions: 1) How is Jewish historical experience represented through literature?; 2) How is Jewish diversity conceptualized in literature? My contribution to this reflection draws on diversity. To illustrate my point, I suggest reading an extract from the autobiographical text of Jewish Mexican-American author, Ilan Stavans, entitled On Borrowed Words, published in 2001 with the sub-title "A Memoir of Language" and translated into Spanish with a new appendix, Palabras prestadas in 2013. With the Jewish Ashkenazim linguistic heritage and (forced) migration experience as point of departure and base, the text, starting right from its title, puts to the fore questions of (linguistic) appropriation, belonging, possession or non-possession in addition to challenging the notion of traditional national/ethnic and even linguistic compartmentalization. Moreover, it deals with the relationship between (appropriated) language and an individual's identity. Further, it possesses paradigmatic traits for human existence in twenty-first century globalized, multilingual and mobile society/ies, despite being a personal reflection on the nineteenth and twentieth century Jewish experience. 


\section{On the author}

Ilan Stavans is a prolific author, active in different genres, whose intellectual biography defies (simple) ethnic, national, and linguistic classifications and categories. Stavans was born in 1961 in Mexico-City as Ilan Stavchansky and son of Ashkenazim parents born in Mexico in 1933 and 1941. Facing pogroms and persecution, his grandparents from maternal and paternal sides migrated to Mexico from Eastern Europe, forming part of Ashkenazim migration to Mexico in the first decades of the twentieth century (cf. Hamui 2007; Dolle 2020). After sojourning in Europe and Israel, Ilan Stavans migrated to the USA in the 1980s and obtained US-American citizenship in 1994. Despite writing most of his works in English, a "foreign language" (Stavans 2002, 184) to him, in addition to migrating to the US and becoming a US citizen, Stavans is still an established author in the canon of Mexican Jewish writers. This is evidenced, e.g., by the article Angelina Muñiz Huberman dedicates to him in the special issue on Jewish Mexican Literature edited by Lockhart in 2013, a crucial anthology taking stock of contemporary Jewish authors.

\section{On the text}

On Borrowed Words is no work of fiction, but presents itself as a "memoir of language", in line with the 2001 subtitle, and as an "autobiografia" in the Spanish version (2013). Therefore, it belongs to the factual genre of life-writing containing autobiographical elements of a person retrospectively narrating episodes from his/her life, accentuating the history of his/her personality (such is Lejeune's classical definition of autobiography, cf. 1975, 14). These elements imply an identity between the narrator and protagonist inside the text using the personal pronoun "I" and the author's name placed on the cover (Lejeune 1975, 14f.), thus evoking an "autobiographical pact". According to Lejeune, this represents a "guarantee" given to the reader that the narrator tells the, or better, his/her "truth", as certain experiences, feelings and states of mind are recollected. However, this is not and cannot be an absolute "truth", as neuroscience research has proven that human memory is, in general, defective and not only adapted to the individual's present situation, but also that memories and gaps therein are quite often marked and over-formed by imagination (cf. Welzer 2017, 19f.). Therefore, it is not astonishing that all too often, the borders between factual and fictional writing are blurred, creating a hybrid genre in-between. 
In Stavans' text, the I-narrator himself is aware of this point, as he writes, "[...] how much of what we are, what we know about ourselves, is really true? We are merely a sum of viewpoints, and human memory is treacherous and inconsistent” (Stavans 2002, 88).

On Borrowed Words is a reflection on the effects of multilingualism on individuals and their identity when passing through and/or living in different cultures. It relates to the Ashkenazi historical experience in the nineteenth and twentieth centuries, characterized by pogroms, persecution, escape, the pinnacle of violence and murder during the Holocaust and, for the survivors, the process of adapting to a new country, which in Stavans' case was Mexico.

Both title and subtitle pinpoint language as a crucial issue, which in a way becomes the focus of the entire book. The preposition "On" makes reference to the metatextual element of language (a nuance that was lost in the Spanish title, Palabras prestadas, where the corresponding preposition "acerca" or "sobre" is missing). Over six chapters, arranged in a more or less chronological order, the first-person narrator ponders upon his own linguistic and intellectual development and aims "to write a memoir about my own upbringing in Mexico and my emigration to America” (Stavans 2002, 87). The narration starts with his childhood in a Yiddish neighbourhood in Mexico-City and moves on to his academic career in Mexico, his trips abroad, his studies in the USA and his US-American nationalization in 1994. The final chapter recounts an encounter with Richard Rodríguez, a latino author who, too, had immigrated to the United States. Rodríguez was one of the first to publish an autobiographical text on the social and linguistic reality of Latin American immigrants in Hunger of memory and thus, conferring visibility to them (1982), an important text for Stavans himself ("the un-self-righteous coming-of-age chronicle of a mestizo Mexican American [...] I have read many times.”; Stavans 2002, 247). ${ }^{1}$

Stavans' point of departure for his reflection on "borrowed" words, words that are obviously not his own, is the experience of (forced) migration of his Ashkenazim grandparents and their approach to, and use of language(s). His grandmother, Bela, wrote a diary addressed to him in Spanish, not in her mother tongue Yiddish, because she wanted to leave behind as a legacy a text that not only her grandson could read, but also her great-grandchildren (cf. Stavans 2002, 51). This circumstance impels him to reflect on her feelings regarding the

1 At the time, Rodríguez made a strong case for monolingualism, the use of English only, because he held that this enables immigrants to (linguistically) assimilate to the new surrounding the greatest extent possible, with Spanish being an obstacle to social rise. This topic is not discussed in Stavans' text, but the intertextual reference can serve to measure the changes in mindset and maybe social standing of a certain language Stavans offensively represents. 
Yiddish language and the role it has been playing for her and other Ashkenazim in Mexico:

The Eastern European settlers, secular in their manner, understood language to be the conduit of tradition. They refused to give it up at the speed of their siblings north of the Rio Grande [...]. Their offspring, to remain Jewish, needed to be raised in the same verbal tradition. And so language was a tool of continuity, the mechanism through which Bela and her peers managed, magically, to go on living, as it were, in Eastern Europe. (2002, 77)

Yiddish, so to say, serves in this context as a heterotopy in Foucaultian sense, "her portable ghetto" (Stavans 2002, 87): "(it) was the umbilical cord with Europe, and was never finally cut” (Stavans 2002, 79). Moreover, with a whole chapter on "The Rise and Fall of Yiddish" (Stavans 2002, 45-90), On Borrowed Words is a de facto homage to Yiddish, the language threatened by extinction, with several Yiddish poems weaving their way through the text. At the same time, his grandmother's text causes him to ponder the (in)adequacy of her Spanish expressions, or a different tone as he notes that

[...] her words have been modified - or shall I say -betrayed-have they not? [...] Her Spanish is pidgin all right-broken, ungrammatical- but it is hers all the same: it has style, it has pathos, it has power. It is the tongue of an immigrant-embryonic, wobbly, in constant mutation. (Stavans 2002, 51f.)

This leads to another key concept that preoccupies Stavans in his "memoir"the "inauthenticity" of the Spanish expressions encountered in his grandmother's text, as Spanish is a language with which she lacked familiarity and that maybe is amending the past: "As I read and reread Bela's diario [...], the word 'inauthentic' comes back to me. I try to imagine how Bela would have written to me in her true tongue: Yiddish". (Stavans 2002, 88) But, that "inauthenticity" that has to do with a switch in language, with a historical decalage ("In seeking words absent from her childhood [...], has she amended her own past?", the Inarrator asks [Stavans 2002, 88]), is not perceived as something negative, but rather an inalienable element of Jewish Ashkenazim linguistic reality following the destruction of their life and culture in Eastern Europe and its insertion into, and existence in a new surrounding (cf. Stavans 2002, 52). Following his grandmother's example, he inscribes himself in this family genealogy, and tries to find, in his own text, an adequate expression for this inauthenticity. This is illustrated by the following quote where the I-narrator presents his linguistic (and poetic) reality to the reader: 


\begin{abstract}
I'm aware that crafting my memoir in English will, in and of itself, be a form of treason. For shouldn't it be written in at least three if not four languages (Yiddish, Spanish, Hebrew, and English), the four tongues in which- and through which-I've experienced life? But no publisher in his right mind would endorse such an endeavor. [...] My aim, nonetheless, is to convey not my nationality but my translationality. To succeed, the original ought to read (sic) as if written already in translation-a translation without an original. I think of the segments in Anglicized Yiddish in Henry Roth's Call It Sleep, and those in "transliterated slang" in Richard Wright's Native Son; they appeal to me because they are bastardized forms of language, polluted, compromised. And an illegitimate language is exactly what I seek. (Stavans 2002, 88)
\end{abstract}

The I-narrator chooses "translationality", a neologism, over "nationality", the latter being a concept that often connects national classification/belonging to a specific official language. Moreover, writers are normally (with exceptions to the rule, of course) expected to write (and often do so) in their native tongue, the language they (are supposed to) know best in its aesthetic, stylistic and connotational facets. The original objective Stavans pursued was to write the autobiographical text in the four languages corresponding to the different phases of his life and acquired in different contexts. He writes, "Yiddish, for me, was truly the mother tongue, whereas Spanish, the street language, the one I most often used, was the father tongue" (Stavans 2002, 83). "Translationality", or "a translation without an original" (see quote above) is not limited to theoretical concepts, such as Derridean deconstructivism, where language and concepts are orbiting a void and permanently deferred, or where the real and true referent (such as truth/God/the Absolute) is and remains absent. Rather, for Stavans, it serves as a metaphor for his human (migrant) condition and, vis-à-vis an increasing global mobility, the rise of transnational groups, communities beyond national concrete territorial borders. Personally, this seems to me not only to be an expression of Jewish, but also modern existence in the twenty-first century.

The benefit of Stavans' text, obvious in the short extracts presented here, is, in my opinion, its provocative approach to national and linguistic affiliation, to the idea that mother tongue(s) are often held to be "pure" and to the high value attributed to perfect linguistic skills (only attainable for native speakers). Furthermore, with his intertextual references, Stavans inserts himself and his concept into USAmerican literary models dealing with the "translation" of voices (i.e. the "Anglicized Yiddish" of Henry Roth), which attempt to transfer orality into written form. The key notion I'd like to highlight here are the terms "polluted", "bastardized" or, to use another theoretical expression that has become en vogue in the last decades, "hybrid", i.e. containing different traits of various origins that do not

2 Hybridity according to Nestor Canclini's ground-breaking book Culturas híbridas (1990) differs 
merge, but rather exist side by side to form something completely new. The adjective "illegitimate" is a counter-project to official, standardized language, or perhaps to academies prescribing or following the ideal of linguistic purity. ${ }^{3}$

Ilan Stavans has experienced a (transgenerational) migration. He is multilingual and uses an aesthetic distance to foreign languages to reflect on his life, career, belonging and multi-rootedness. The distance to his mother tongue(s), (the) language(s) one was brought up with, is experienced as fructiferous and vivifying. As stated by the author himself in the newly added appendix in Palabras prestadas, English is the first language he explicitly chose, whereas the others were "accidental”:

[...] quería escribir una memoria políglota, es decir, la primera parte de mi vida idish (la escuela y mi relación con la generación emigrante de la comunidad judía) sería redactada directamente en la lengua de Sholem Aleichem; la porción vivida en español (la vida de la calle y mi descubrimiento de México) sería en la lengua de Cervantes [...]; después el hebreo (la lengua del sionismo y de Israel, en donde pasé mis años formativos) [...]. Las memorias terminarían con una parte escrita en inglés, la lengua que he adoptado desde que me mudé a los Estados Unidos. [...] Necesitaba escoger un solo idioma. O, mejor dicho, una lengua necesitaba escogerme a mí. Nunca hubo duda de que fuese el inglés: es el único idioma que he escogido libremente, mi relación con los otros tres fue meramente accidental (Stavans 2013, 281).

\section{Concluding remarks}

To take up my introductory remarks, syllabi are not only valuable and extremely important for academic education and, especially, teacher training, but also for high school and all forms of secondary school (not only in the respective German federal Länder). It is widely known and has been proven by research that first and decisive mind sets regarding societal values are formed at school. This is why the importance of syllabi and school books should not be underestimated. ${ }^{4}$ This is also why Jewish literature concerning diversity and historical experience should not only be disseminated at university, but also during the formative years at school.

by far from that of Mexican intellectual Vasconcelos' notion of a "raza cósmica" (1925), considered as a melting pot, where all differences merge into a harmonic equal new form.

3 In my option it is therefore only logical that Ilan Stavans is a fervent proponent for other forms of hybrid languages, such as Spanglish, which - according to him - correspond(s) to the real life of a considerable number of Latinos in the US.

4 Cf., e. g., Constantin Schreiber's recent study on school books in Muslim countries, Die Kinder des Koran. Düsseldorf: Econ 2019, with the conclusion that the analyzed corpus contains an extremely stereotyped representation of Jewish people and distorted historical events. 
In this context, I'd like to offer another and final comment on issues surrounding school politics. Secondary/high schools shape the demand and supply of philological study programmes (in Germany and, I assume, in other countries as well). Despite the current official EU-based, foreign-language friendly policies in place (i.e. not only the promotion of English), the concrete situation at schools in several Länder has shown that there is not only a strong competition between the second and third foreign modern language offered at secondary/high schools over the last few years, but also that options and possibilities to pursue two Romance languages are restricted more and more ${ }^{5}$. In reality, this restriction in diversity has already shown consequences in the form of a declining number of students taking up Romance (philological) studies at university. Even if this is not the only reason for the decline in demand for studies in philology, one should be aware of this challenge in order to able to better disseminate Jewish literature in the forthcoming decades.

\section{Bibliography}

Bär, Marcus. "Französisch, Spanisch, Italienisch - Zur Stellung der romanischen Schulsprachen im deutschen Bildungssystem”. FLuL 46.1 (2017). 86-99.

Dolle, Verena. "Intercultural memory and violence in Jewish literature." The Cambridge Handbook of Intercultural Communication. Eds. Guido Rings and Sebastian Rasinger. Cambridge: UP, 2020. 302-318.

Hamui, Liz. "Mexico." Encyclopedia Judaica, vol. 14. Eds. Michael Berenbaum and Fred Skolnik. Detroit: Macmillan Reference, ('2007). 137-146. https://jwa.org/encyclopedia/ article/mexico (October 17, 2019).

Lejeune, Philippe. On Autobiography. Minneapolis: Univ. of Minnesota Press 1989 (1975). Muñiz Huberman, Angelina. "Ilán Stavans: la memoria en juego." Critical Approaches to Jewish-Mexican Literature. Ed. Darrell Lockhart (= Chasqui. Revista de literatura latinoamericana. Special Issue No. 4). 219-230.

Rodriguez, Richard. Hunger of memory: the education of Richard Rodriguez, an autobiography. New York, NY: Dial Press, 2005 (1982).

Schreiber, Constantin. Die Kinder des Koran. Düsseldorf: Econ, 2019.

Stavans, Ilan. On Borrowed Words. A Memoir of Language. New York: Penguin, 2002 ('2001). Stavans, Ilan. Palabras prestadas. Autobiografía. Traducción de Lety Barrera. México D.F.: FCE, 2013.

Welzer, Harald. Das kommunikative Gedächtnis. Eine Theorie der Erinnerung. München: Beck, 2017 (2002).

5 Cf. Marcus Bärss, differentiated consideration of the standing of Romance languages in German educational system, especially his concluding remarks (2017, 96f.). 
